Yüzüncü Yil Üniversitesi
Tarim Bilimleri Dergisi

Research Article (Araştırma Makalesi)

Use of Sucrose in Propagation of Snowdrop Bulb**

\author{
Özgür KAHRAMAN*1 \\ Canakkale Onsekiz Mart University, Faculty of Architecture and Design, Department of Landscape Architecture, \\ 17020 Canakkale, Turkey \\ ${ }^{1}$ https://orcid.org/0000-0003-1336-9942 \\ * Corresponding author e-mail: ozgurkahraman@comu.edu.tr
}

\section{Article Info \\ Received: 28.01.2020 \\ Accepted: 10.04.2020 \\ Online Published 30.06.2020 \\ DOI: $10.29133 /$ yyutbd.680442}

\section{Keywords}

Bulblet enlargement, Bulb,

Geophyte,

Propagation,

Sucrose.

\begin{abstract}
Taurus snowdrop is one of the species exported with the quota limitation. Growing bulb in a short time is an important issue in terms of production. This research was performed so as to specify impressions of varied sucrose rates on the bulblet formation and growing. Galanthus elwesii Hook. (Taurus snowdrop) bulbs with a circumference of $4 \mathrm{~cm}$ obtained from a private company were used in this study. After the bulbs were cleaned, they were vertically divided into four segments (chips) and the chips were put on plastics bags with perlite. After adding perlite to the bag, city water (control), 1\% sucrose and $2 \%$ sucrose solution were given to the bags filled with perlite to form bulblet from Taurus snowdrop chips in incubation. Incubation was done in storeroom at 18-20 ${ }^{\circ} \mathrm{C}$ temperature. At the end of the incubation, the bags were emptied and measurements were performed. According to statistical analysis; the impression of varied sucrose levels on the number of bulblet, bulblet and segment weight, bulblet height and bulblet weight was insignificant. The bulblet number ranged from 1.00 to 1.33 piece and the bulblet weight ranged from 0.16 to $0.33 \mathrm{~g}$. As sucrose dose increased, bulblet diameter increased. The impression of varied sucrose levels on bulblet diameter was statistically significant $(\mathrm{p}<0.05)$. The highest bulblet diameter was obtained in $2 \%$ sucrose $(6.28 \mathrm{~g})$ and $1 \%$ sucrose (5.54 g) treatments.
\end{abstract}

\title{
Kardelen Soğan Çoğaltımında Sakkaroz Kullanımı
}

\section{Makale Bilgileri}

Geliş: 28.01.2020

Kabul: 10.04 .2020

Online Yayinlanma 30.06.2020

DOI: 10.29133 yyutbd.680442

\section{Anahtar kelimeler}

Yavru soğan büyütme,

Soğan,

Geofit,

Çoğaltma,

Sakkaroz.
Öz: Toros kardeleni ihracatı kota sınırlaması ile yapılan türlerden birisidir. Soğanın kısa süre içinde büyütülmesi üretim yönünden önemli bir konudur. Bu çalışma Toros kardeleni çoğaltmada değişik sakkaroz düzeylerinin yavru soğan oluşum ve gelişimindeki etkilerini belirlemek amacıyla yapılmıştır. Denemede özel bir firmadan temin edilen $4 \mathrm{~cm}$ çevre uzunluğuna sahip Galanthus elwesii Hook. (Toros kardeleni) soğanları kullanılmıştır. Soğanlar temizlendikten sonra dikey olarak dört dilime ayrılmış ve dilimler perlit dolu torbalara yerleştirilmiştir. Torbalara perlit ilave edildikten sonra, Toros kardeleni dilimlerinden inkübasyonda yavru soğan oluşturması için perlit dolu torbaların içine çeşme suyu (kontrol), \%1 sakkaroz ve \%2 sakkaroz çözeltisi verilmiştir. İnkübasyon 18$20{ }^{\circ} \mathrm{C}$ sıcaklıkta adi depoda yapılmış. İnkübasyon bitiminde torbalar boşaltılmış ve ölçümler gerçekleştirilmiştir. Yapılan istatistiksel analizlere göre; farklı sakkaroz düzeylerinin yavru soğan sayısı, yavru soğan ve parçacık ağırlığı, yavru soğan yüksekliği ve yavru soğan ağırlığı üzerine etkisi önemsiz bulunmuştur. Yavru soğan sayısı $1.00-1.33$ adet arasında, yavru soğan ağırlığı $0.16-0.33$ g arasında değişmiştir. Artan sakkaroz dozları ile yavru soğan çapı artış 
göstermiştir. Farklı sakkaroz düzeylerinin yavru soğan çapı üzerine etkisi istatistiksel olarak önemli olmuştur $(\mathrm{p}<0.05)$. En yüksek yavru soğan çapı $\% 2$ sakkaroz (6.28 g) ve \%1 sakkaroz (5.54 g) uygulamalarından elde edilmiştir.

\begin{abstract}
${ }^{* *}$ This article was presented on April 26-29, 2018 at the $2^{\text {nd }}$ International Vocational Science Symposium (IVSS 2018) and its abstract book.
\end{abstract}

\title{
1. Introduction
}

Turkey has quite rich plant gene resources. Turkey taking place at the crossing of three phytogeographical regions, having different types of climate, soil types, altitude changes at short distances and geographical formations increase the plant diversity (Karagüzel, 2010; Avc1, 2014; Koyuncu and Alp, 2014). The number of plant species naturally spreading to Turkey is close to the plant species number in Europe. Approximately 12000 plant taxa is located in Turkey and 3646 of them are endemic taxa (Güner et al., 2012). There are 1056 taxa geophytes spreading naturally (Özhatay, 2013). Geophyte means ground plants and these plants have an underground stems metamorphosed like tubers, bulbs, rhizomes and corms. They are known "flower bulbs" and have flashy flowers for a short time. After their aboveground parts complete the development, they turn yellow and dry. They survive with underground storage organs such as bulbs, tubers, rhizomes and corms in the summer. These plants are used as ornamental plants and medicinal plants therefore, these plants have economic value. Turkey has revenues of approximately $\$ 2.5$ million from naturel flower bulbs export per year. The export of natural flower bulbs is arranged by the legal arrangement on collecting, growing and exporting of natural bulbs from nature (Resmi Gazete, 2018). The bulletin published every year describes plant species, circumference length, quantity and source about the export of natural flower bulbs. In 2019, eight natural flower bulbs were permitted to export with a quota limitation. Galanthus elwesii (Taurus snowdrop) bulbs with a circumference of more than $4 \mathrm{~cm}$ are allowed to export. 3 million bulbs of them were from nature and 4 million of them were from production (Resmi Gazete, 2018). Taurus snowdrop can be propagated with vegetative and generative methods. In order to reach the size of the bulb that can bloom with generative method, it takes a long and laborious period such as 5-6 years. This period is shorter in vegetative methods such as chipping and twin scaling. The diameter of the bulblet obtained in the vegetative method varies according to the initial bulb size and the number of segment (chip). The bulblet diameter is positively correlated with the initial bulb size and negatively with the chip number (Aksu and Celikel, 2003; Seyidoğlu, 2009). If the larger bulblet diameter is desired, the larger bulb size should be preferred. If a large number of small bulblet is wanted, initial bulb should be divided into more segment. The companies that produce flower bulbs generally want to obtain a wide range of bulb and large bulb in a short span of time.

The research was realized to specify the impressions of varied sucrose rates on the bulblet formation and growing in propagation of Taurus snowdrop. Thus, it is aimed to develop alternative methods that can be applied to bulblet enlargement.

\section{Materials and Methods}

The research was carried out between February 2, 2017 and April 15, 2017 in storeroom with 18-20 ${ }^{\circ} \mathrm{C}$ temperature. Galanthus elwesii Hook (Taurus snowdrop) was used as a propagation material in the experiment. Taurus snowdrop bulbs obtained from a private company exporting natural flower bulbs were kept in plastic crates in a cool and shaded area until the time of propagation. Before cutting bulbs, the dry root and outer coarse tunic of all bulbs were cleaned by hand and classified according to their circumference. After sorting, healthy Taurus snowdrop bulbs with a circumference of $4 \mathrm{~cm}$ were selected for use in the cutting process and the outer tunic of the selected bulbs were cleaned until white bulb scale appeared. Their bulb base and bulb nose were cut with stationery knife and these bulbs were wiped with alcohol (Figure 1). 


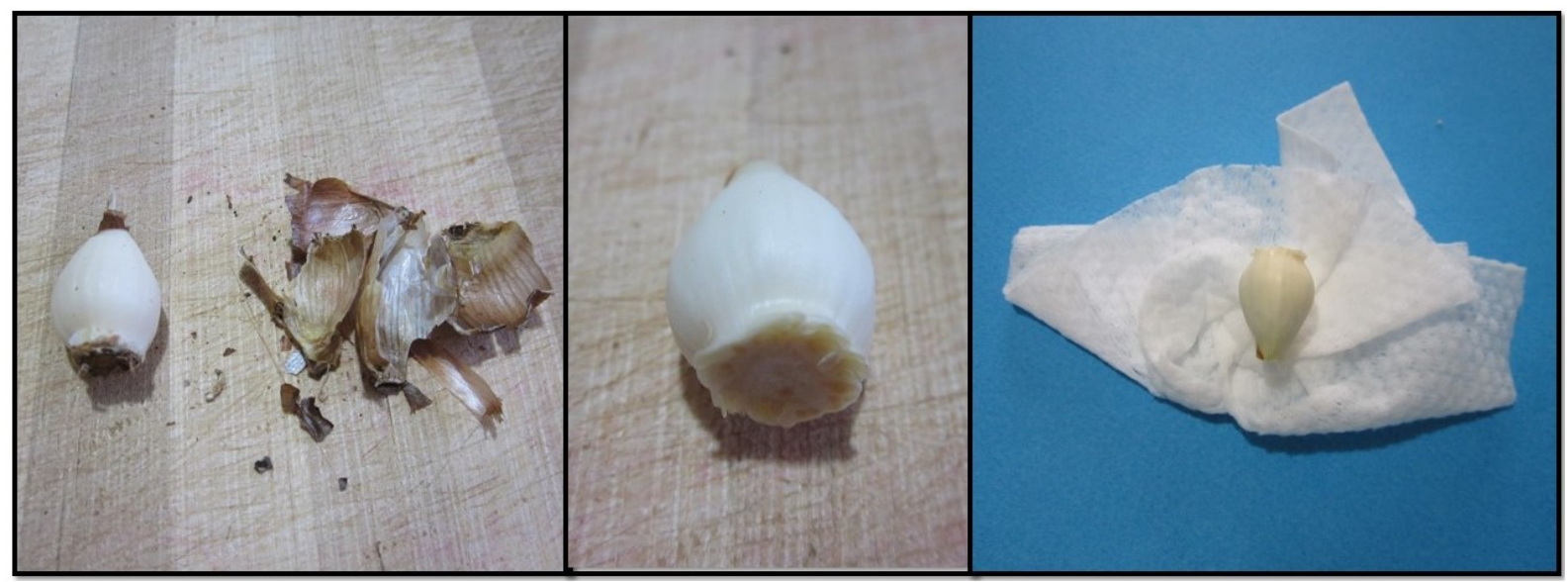

Figure 1. Preparation of Taurus snowdrop bulbs for cutting.

During the cutting process, bulb, stationery knife and cutting surface were wiped with alcohol and then the cutting surface was cleaned with sodium hypochlorite solution (5\%). The bulbs were cut vertically with the stationery knife two times and so that four chips were obtained from each bulb (Figure 2). The particles (segments) obtained by chipping method were put into mesh bags and the particles were kept in solution containing $0.5 \%$ Mancozeb and $1 \%$ Captan for 20 minutes against fungal growth. The chips taken out the solution were left in the plastic casing to allow excess solution to flow and to dry a little. 5 liter black plastic bags were filled with 3 liters of perlite and 10 chips in two rows were placed for each bag on 2 February 2017. Later, the chips were covered with 2 liters of perlite. The perlite filled bags were given city water (control), $1 \%$ sucrose and $2 \%$ sucrose solution to form bulblet from Taurus snowdrop particles on 2 February 2017 (Figure 3). Irrigation was continued according to the moisture of perlite during incubation.

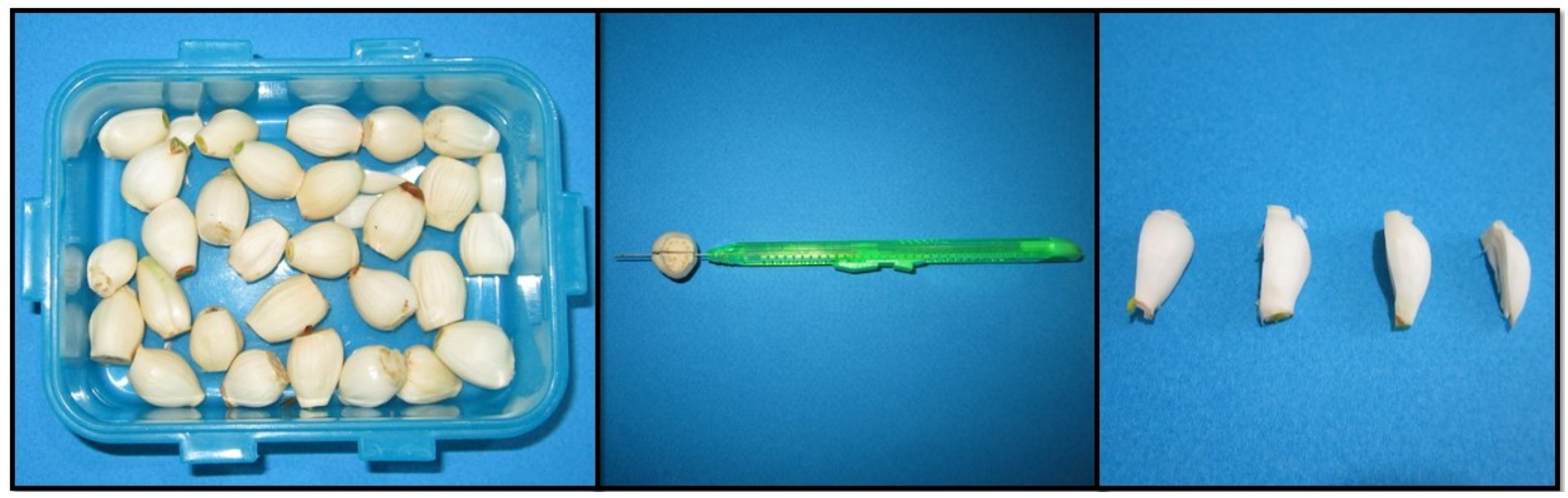

Figure 2. The process of bulb segmentation.

The chips in the perlite were incubated until April 15, 2017 under storage at $18-20{ }^{\circ} \mathrm{C}$ to form bulblet. The experiment was arranged according to randomized plot design with three replications and 10 particles (chips) were used in each replication (bag). The bags were emptied at the end of the incubation and the number of the bulblet (piece), the weight of the bulblet and segment (g), the diameter of the bulblet $(\mathrm{mm})$, the height of the bulblet $(\mathrm{mm})$ and the weight of the bulblet $(\mathrm{g})$ were measured. Variance analysis (ANOVA) and Duncan multiple comparison test $(\mathrm{p}=0.05)$ were performed by SPSS 23 statistical program. 


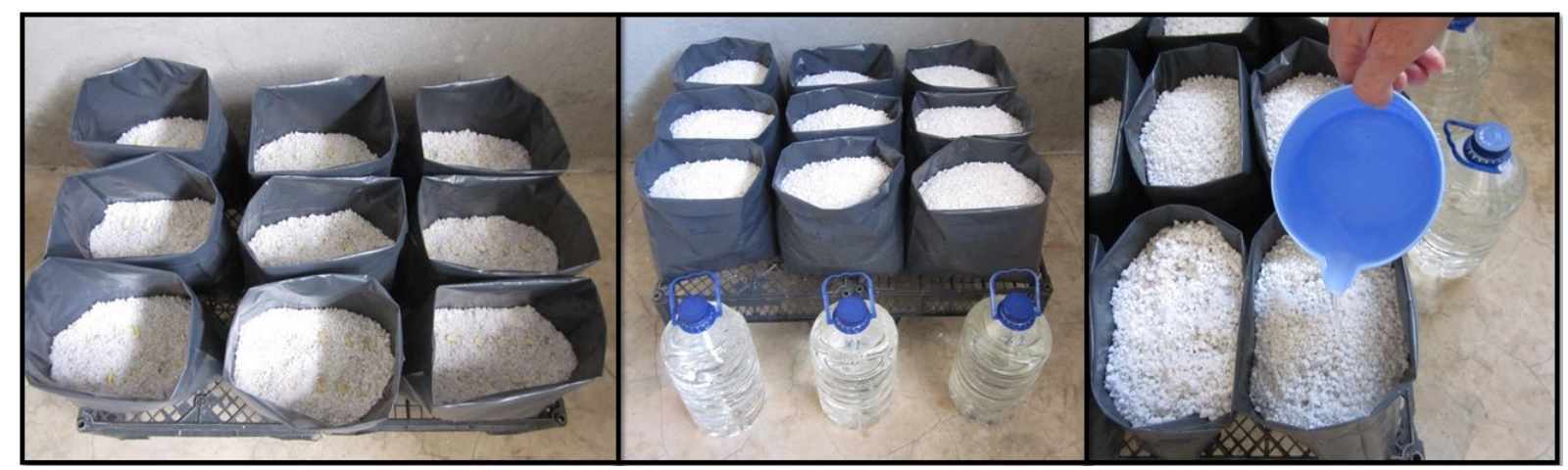

Figure 3. Planting chips and solution application.

\section{Results}

According to the analysis of variance; varied sucrose levels had no effect statistically on the bulblet number, the weight of the bulblet and segment, bulblet height and bulblet weight but their effect on bulblet diameter was significant $(\mathrm{p}<0.05)$. The number of bulblet was between 1.00 and 1.33 pieces (Figure 4). As a numerical value, the number of bulblet in the control application reached higher values (1.33) and bulblet number in the sucrose applications was 1.00 piece.

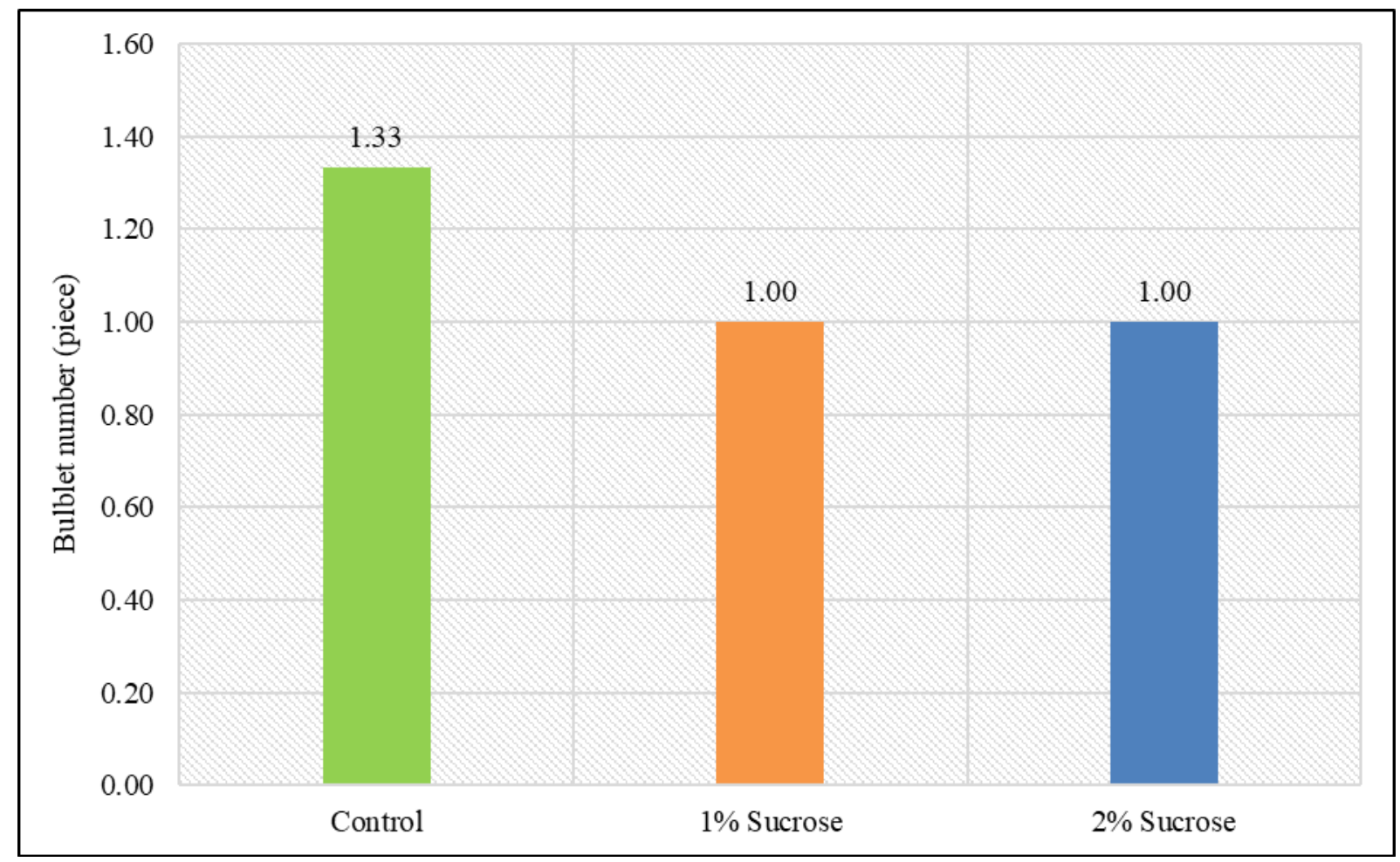

Figure 4. The effect of sucrose applications on the bulblet number.

Bulblet and segment weight were higher in the application of $1 \%$ sucrose as numerical value. Bulblet and segment weight ranged from $0.83 \mathrm{~g}$ to $0.91 \mathrm{~g}$ (Figure 5). 


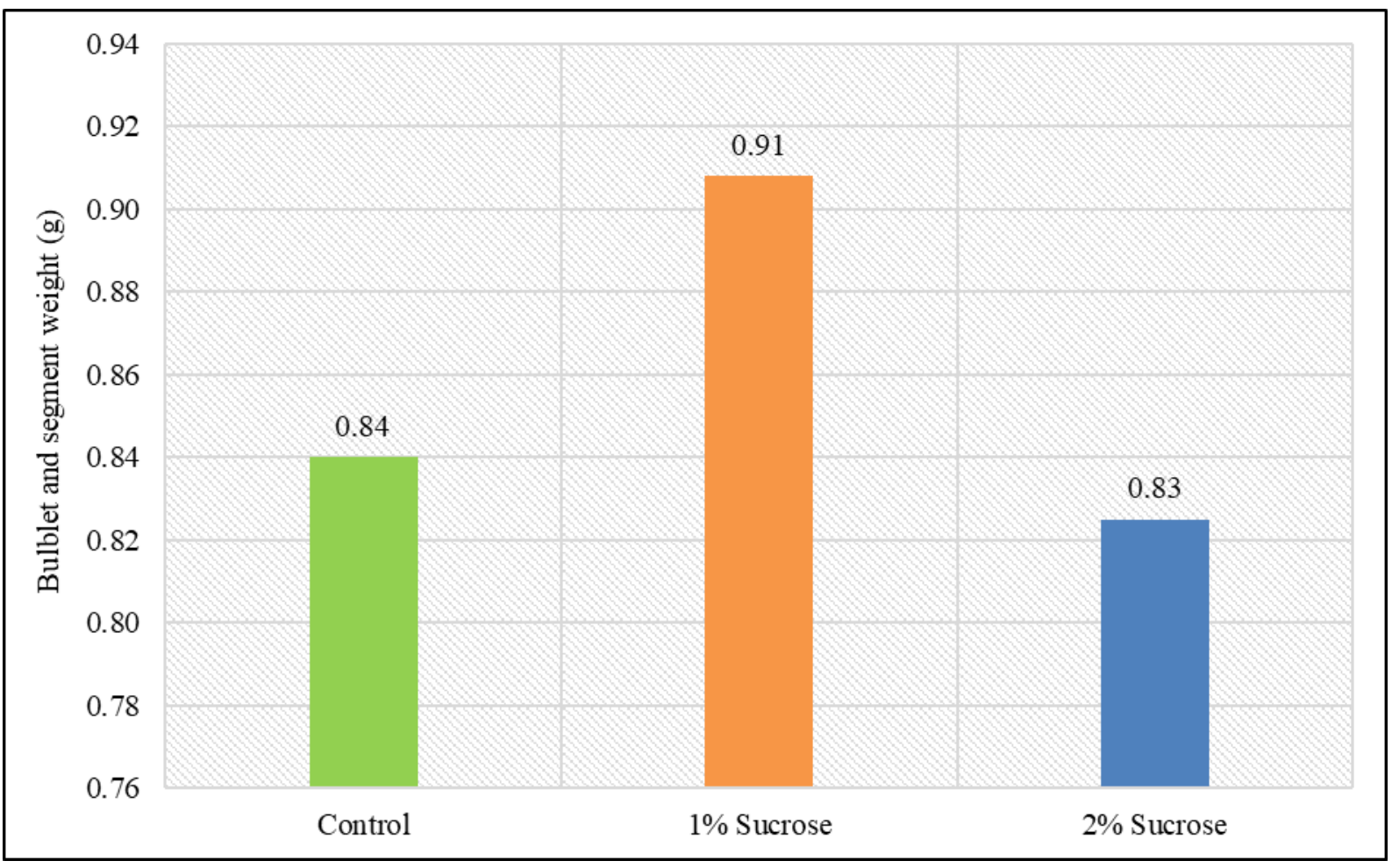

Figure 5. The effect of sucrose applications on bulblet and segment weight.

The effect of sucrose applications on bulblet diameter was found to be statistically significant $(\mathrm{p}<0.05)$. The highest bulblet diameter was acquired from applications of $2 \%$ sucrose $(6.28 \mathrm{~mm})$ and $1 \%$ sucrose $(5.54 \mathrm{~mm})$. Control application was included in the second statistical group (Figure 6). With increased sucrose rates, bulblet diameter increased.

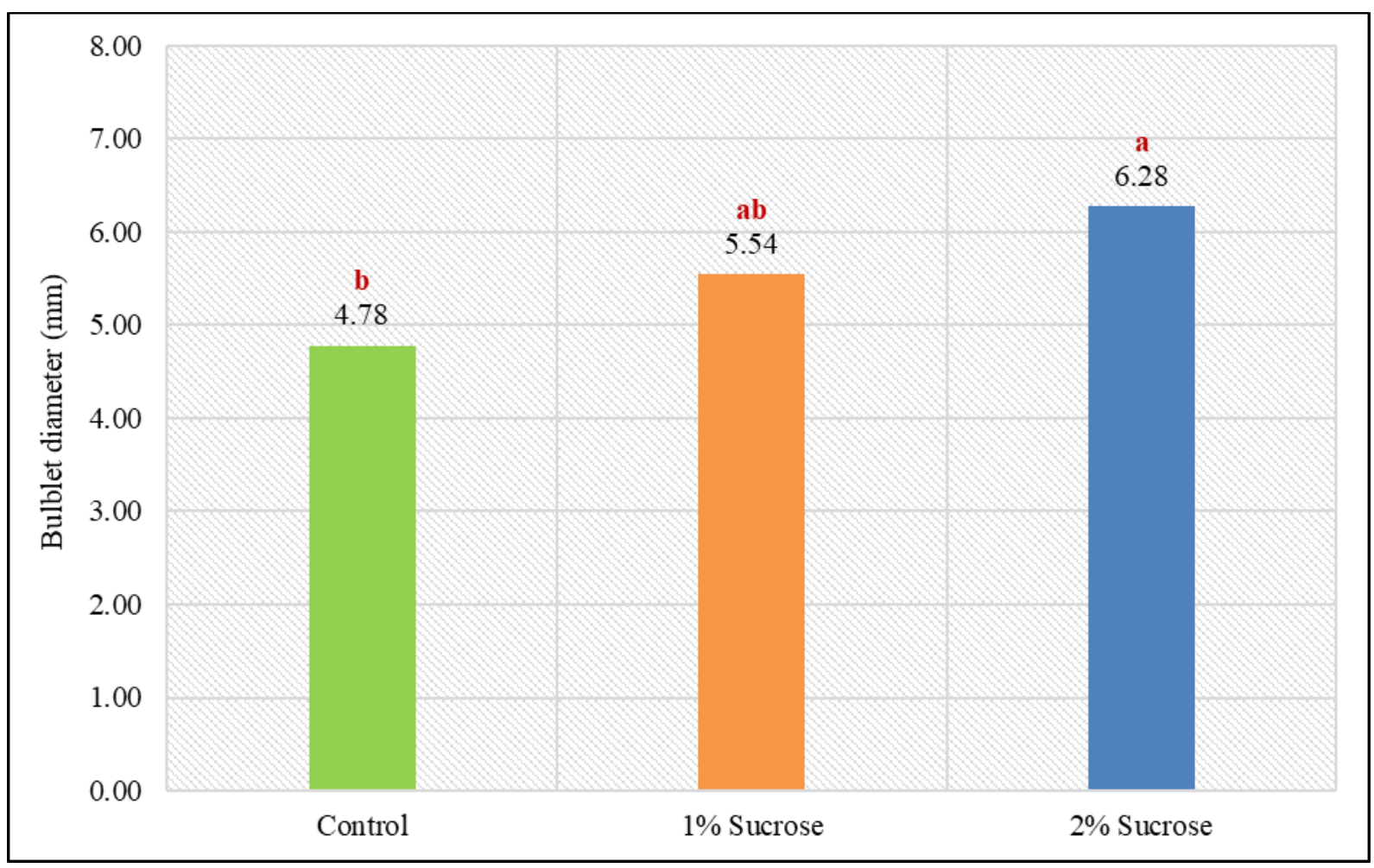

Figure 6. The effect of sucrose applications on bulblet diameter. 
Although the effect of sucrose applications on the bulblet height is statistically insignificant, the bulblet height increased with increased sucrose rates (Figure 7).

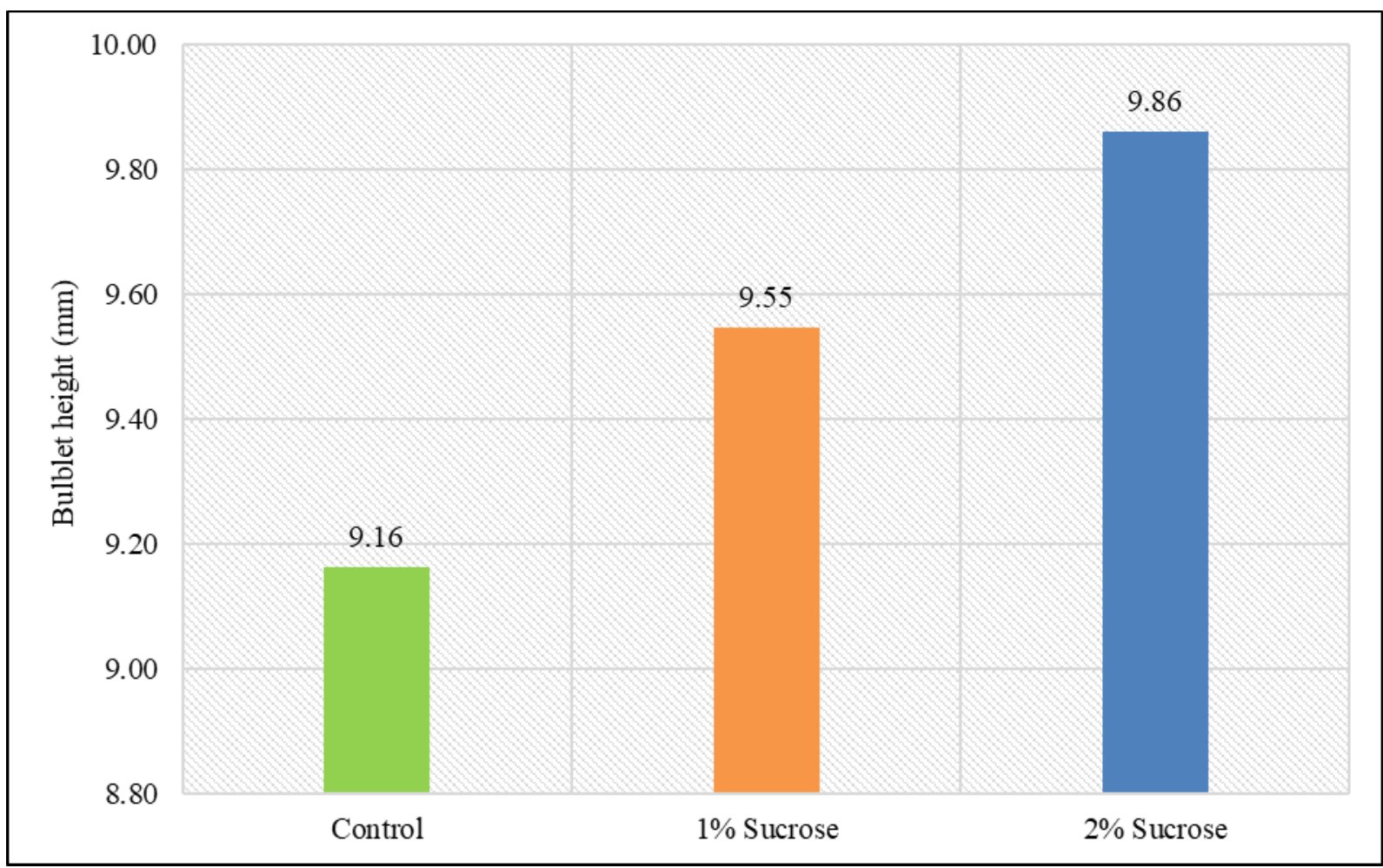

Figure 7. The effect of sucrose applications on the bulblet height.

There was no statistical difference between applications in bulblet weight. According to sucrose applications, the bulblet weight in the control was high in value (Figure 8).

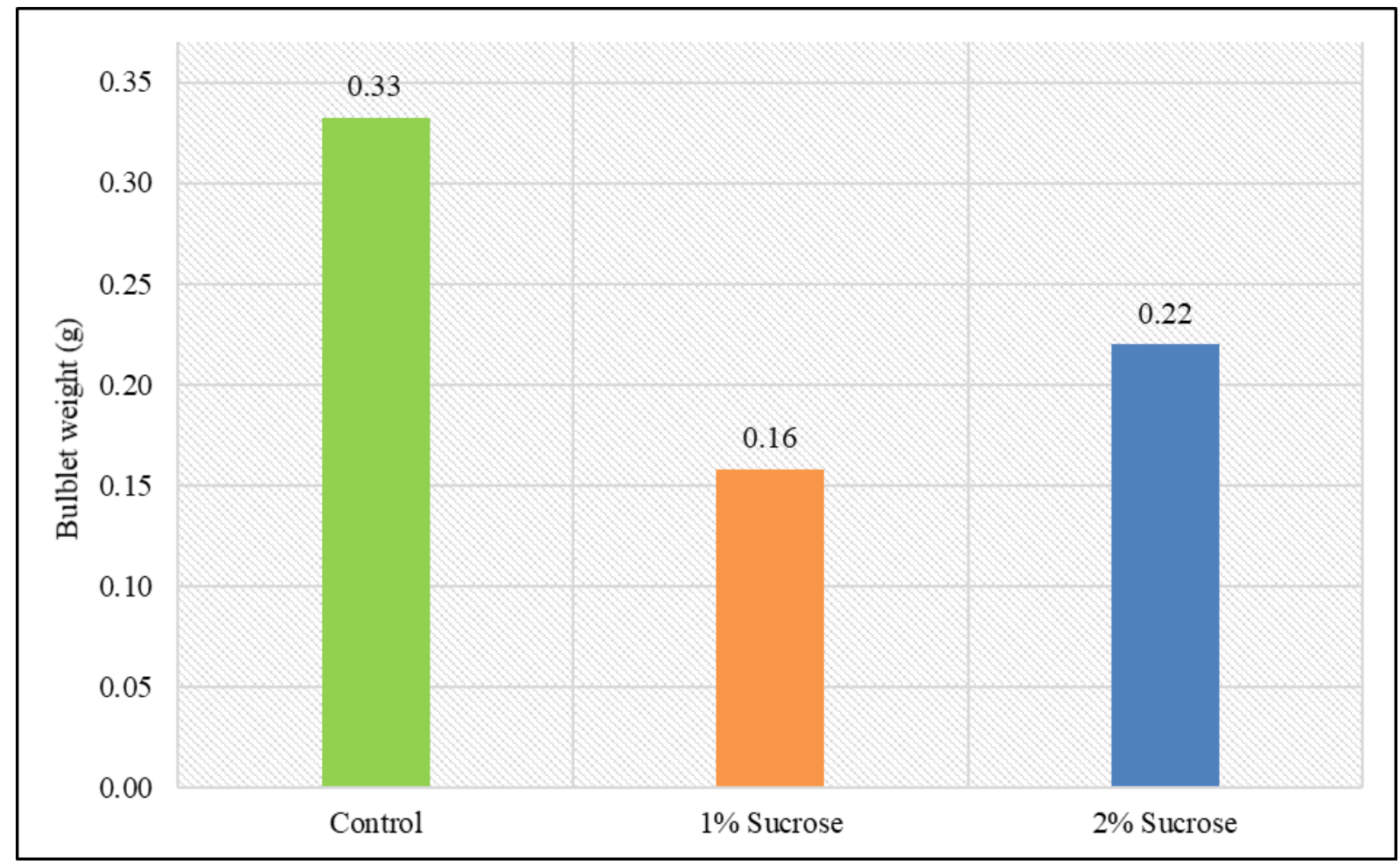

Figure 8. The effect of sucrose applications on bulblet weight. 


\section{Discussion and Conclusion}

Sucrose applications at different rates positively affected the bulblet diameter. With the increased rates of sucrose, there was an increase in the diameter and height of the bulblet. Decrease in bulblet weight values was determined according to the control application. Aksu et al. (1998) in the snowdrop propagation of 4-5 cm and 5-6 cm circumference, they found the number of bulblet per segment between 0.88-1.39 pieces and the bulblet length between 3.4 and $6.5 \mathrm{~mm}$. Aksu and Çelikel (2003) found that the propagation ratio was $2.6 \mathrm{~mm}$ and the bulbil length was $6.6 \mathrm{~mm}$ in propagation of snowdrop bulb with a circumference of 5-6 cm. They determined that with the initial bulb diameter increasing, the propagation rate and bulbil diameter increased. Kahraman and Özzambak (2006) determined that the propagation rate of snowdrop bulb with an initial diameter of $19-21 \mathrm{~mm}$ was $96.7 \%$, the bulblet diameter was $0.80 \mathrm{~cm}$ and the bulblet weight was $0.57 \mathrm{~g}$. This study is similar to the above studies. However, since the initial bulb used in this study was lower, the bulblet diameter and bulblet weight were lower. Kahraman (2019) found the effect of varied sucrose doses on the bulblet number, bulblet weight, bulblet diameter and bulblet height was insignificant in the propagation of summer snowflake. Alike results were obtained in the research. Moreover, the bulblet diameter increased with increasing sucrose rates in this study. These studies show that plant species are affected differently by sucrose rates in bulb propagation. In addition, the diameter of the bulb used in propagation has a positive effect on the bulblet number, bulblet diameter and bulblet weight. $2 \%$ sucrose application may be preferred in the bulb propagation of the snowdrop. Future studies will be useful on different plant species and different sucrose doses in terms of growing bulblet.

\section{References}

Aksu, E., Görür, G., \& Çelikel, F.G. (1998, Ekim). Kardelenin (Galanthus elwesii Hook.) bölme (chipping) yöntemi ile üretilmesi üzerinde bir araştırma. I. Ulusal Süs Bitkileri Kongresi, Yalova.

Aksu, E., \& Çelikel, F.G. (2003). The effect of initial bulb size on snowdrop (Galanthus elwesii Hook. f.) bulb propagation by chipping. Acta Horticulturae, 598, 69-72.

Avcı, M. (2014). Türkiyenin Doğal-Egzotik Ăgaç ve Çallları I, edition: I., chapter: Türkiyenin bitki çeşitliliği ve coğrafi açıdan değerlendirmesi. Orman Genel Müdürlüğü Yayını, editör: Akkemik Ü, 28-53, Ankara.

Güner, A., Aslan, S., Ekim, T., Vural, M., \& Babaç, M.T. (2012). Türkiye Bitkileri Listesi Damarlı Bitkiler. Nezahat Gökyiğit Botanik Bahçesi ve Flora Araştırmaları Derneği Yayını, Flora Dizisi 1, s1290, İstanbul.

Kahraman, Ö., \& Özzambak, M.E. (2006, Kasım). Kardelen soğanlarının vegetatif yöntemlerle üretim olanaklarl ve topraksı tarım yöntemiyle yetiştirilmesi. III. Ulusal Süs Bitkileri Kongresi, İzmir.

Kahraman, Ö. (2019). Göl soğanı çoğaltımında sakkaroz oranlarının etkisi. Kahramanmaraş Sütçü İmam Üniversitesi Tarım ve Doğa Dergisi, 22(3), 399-406.

Karagüzel, O. (2010, Ekim). Bitki genetik kaynaklarımızın peyzaj açısından değerlendirilmesi. IV. Süs Bitkileri Kongresi, Erdemli, Mersin.

Koyuncu, M., \& Alp, Ş. (2014). New geophyte taxa described from Turkey at last decade. Yüzüncü Yıl Üniversitesi Tarım Bilimleri Dergisi (YYU J AGR SCI), 24(1), 101-110.

Özhatay, N. (2013, Mayıs). Türkiye’nin süs bitkileri potansiyeli: doğal monokotil geofitler. V. Süs Bitkileri Kongresi, Bildiriler Cilt:1, Yalova.

Resmi Gazete. (2018). Doğal çiçek soğanlarının 2019 yılı ihracat listesi hakkında tebliğ (tebliğ no: 2018/49). Resmi Gazete, Say1:30623, 12 Aralık.

Seyidoğlu, N. (2009). Leucojum aestivum L'nin parçacık tekniği ile üretimi. Bartın Orman Fakültesi Dergisi, 11(16), 7-11. 